\title{
Export Function of Cocoa Production, Exchange Rate Volatility and Prices in Nigeria
}

\author{
Alaba David Alori ${ }^{1}$ Adebayo Augustine Kutu ${ }^{2}$ \\ ${ }^{1}$ Department of Agricultural Economics \& Extension, Federal University of Technology, Minna, Nigeria \\ ${ }^{2}$ School of Accounting, Economics \& Finance, University of KwaZulu-Natal, South Africa \\ ade_kutu@yahoo.com
}

\begin{abstract}
This study examined the export function of cocoa production and determined the impact of exchange rates and price volatility on the exportation of cocoa in Nigeria. The Phillips-Perron (PP) and Augmented Dickey-Fuller (ADF) unit root tests, Ordinary Least Square (OLS) and Structural Vector Autoregressive (SVAR) methodologies were employed to analyse the time series data that spanning from 1970:01 to 2016:12. The PP and ADF unit root tests findings indicated that none of the variables was stationary at levels (I (0)) however, after the first difference I (1) they became stationary. At 5\%, the OLS results showed that all the variables were statistically significant in analysing the effects of exchange rates and price volatility on the value of cocoa production in Nigeria. The price of cocoa in the international market and the value of exchange rates play a significant role in cocoa exports growth in Nigeria. Further, findings from the SVAR showed that an increase in the price of cocoa would increase cocoa production and cocoa export growth in Nigeria, while the exchange rate volatility would affect cocoa export growth in Nigeria. The result further revealed that the shocks to exchange rate accounted for the greater volatility (positively significant for the entire period) to the value of cocoa exported, as against other variables in the model. Based on those findings, the paper, therefore, recommends that there should be a free exchange rate market determination, in order to enhance the export growth and increase cocoa output in Nigeria.
\end{abstract}

Keywords: Cocoa production, exchange rate volatility and prices.

\section{Introduction}

The cocoa sub-sector of the Nigerian economy has received increasing attention as an essential part of the current economic reform agenda of the federal government on diversification of the nation's export base from crude oil and boost agricultural production. The performances of the agricultural export fell below equality and the agricultural sector experienced a persistent decline after economic reform undertaken through the Structural Adjustment programme (SAP) of 1986 whereas this sector was a major contributor to Nigeria's foreign exchange earnings. Prior to the 1980s, cocoa was a major source of foreign exchange earnings, the leading agricultural export commodity and economic development in Nigeria (Abang \& Ndifon, 2002; Nkang et al., 2006). Through the devaluation of the Nigerian naira in 1986, the demand for agricultural products was increased while its price was raised over the years (Adubi \& Okunmadewa, 1999). There was instability of the exchange rate movement due to the devaluation policy and this raised concerns about the effect of such policy on the flow of agricultural trade in the Nigerian economy (Okunmadewa, 1999). Both the exchange rates and prices of cocoa export in Nigeria between 1970 and 1977 were stable. This stability was attributed to the Nigeria Commodity Board (NCB) policy impacting on the controlled export prices.

However, there was an exchange rates upsurge, between 1978 and 1982, exasperated by the introduction of both dollars pegged systems and managed float of exchange rate policies in the Nigerian economy. Hence, this fluctuation declined the quantity of exportation of cocoa. In view of the instability of exchange rate, price volatilities and the declining trend of the quantity of cocoa export, this study examines the export function of cocoa production and determines the impact of price and exchange rate volatility on cocoa export growth in Nigeria. Although the impacts of volatilities of exchange rate on international agricultural trade have been investigated by some scholars (Weersink et al., 2008; IFPRI, 2011; Braun \& Tadesse, 2012), however, the impacts of price volatility have not been largely investigated in the extant literature, hence, this paper tends to contribute to the body of knowledge. Following this introduction other sections of this paper is structured as follows: Section 2 is the justification of the study; Section 3 is a brief review of the empirical research; Section 4 outlines the methodology employed; Section 5 presents the empirical results and data analysis, while Section 6 concludes the paper by explaining the summary of the findings with empirical comparisons from Nigeria. 
Justification of the Study: Since the collapse of the Bretton Woods system of the 1970s, researchers became interested in the impacts of exchange rate volatility on exports due to the fact that among major currencies in the world, fixed exchange rates system was allowed to float. Changes in income earnings of export crop producers come as a result of either the devaluation of the currency, a decrease or increase in the international price of exports, and the subsequent increase in producer prices. Such exchange rate/price changes if they are erratic could, however, result in a large reduction in future output. Fluctuations, either positive or negative, are not desirable as they increase uncertainty and risk in international transactions and bye and bye, trade is discouraged. A study conducted by the IMF (1984) indicated that volatility in the exchange rate when compared to currency in term of foreign ones is a random movement of domestic prices. Price instability and Exchange rate volatility result in uncertainties and risks in the international market and thereby discouraging trade. The risk involved in exchange rate measures the erratic pattern and volatility of movement in the exchange rate. The more volatile the movement, the greater the uncertainty and risks involved and this eventually leads to price instability. The prices the producers receive appear to be main concern of the producers; hence, they are mostly interested in the price stability of such products, as it relates to earning a consistent income. Therefore, one of the factors that have been identified as a determinant of price instability is exchange rate volatility, and this is impacting on cocoa production and export of cocoa in Nigeria. Hence, the need to be empirically resolved and studies this concept more closely.

\section{Empirical Review on Price and Exchange Rate Volatility and Agricultural Trade}

Despite the numerous extant literature on the impact of exchange rate volatility on trade, it appears that no existing study has simultaneously explored the contribution of price volatilities and exchange rate on agricultural trade (though such studies have been conducted separately) in Nigeria. Agricultural trade has been found to be more sensitive to uncertainties of exchange rate in the developing countries when compared to other sectors. Adopting a sample of the flow of bilateral trade across G10 nations, when compared to other sectors, Chou et al. (2000) indicate that the real exchange rate uncertainty has had a significant negative effect on agricultural trade. Again, Kandilov (2008) argues that when compared to exporters in the developed countries, the impact of exchange rate volatilities is higher for developing country exporters. Hence, he concludes that agricultural exports among the developing economies are more susceptible to exchange rate volatilities, as compared to developed countries. In addition, Villanueva and Sarker (2009) conducted a study to investigate the impacts of exchange rate volatility on the importation of fresh tomato into the United States from Mexico. Adopting the cointegration analysis, the study indicated that while changes in exchange rate have a positive impact on trade flows; volatility of the exchange rate has a significant negative contribution to the flow of trade.

A similar study was again conducted in Cameroon, on the behavior of agricultural export by Tshibaka (1997). He estimated the impacts of exchange rate policies on crop prices on Cameroon's agricultural export competitiveness. The outcome of the study indicates that exchange rate volatility has a significant negative impact on the flow of trade. Several other researchers such as Johnson et al. (1977), Schwartz (1986), Bradshaw and Ordan (1990), Denbaly and Torgerson (1992), Babula et al. (1995), Kiptui (2007), Aliyu (2008) and Oyinlola (2008), all investigated the impact of exchange rate volatility on agricultural trade and showed that exchange rate volatility has a significant effect on the export of agricultural product. The volatile market prices has indicated that price volatility is probably one of the main sources of risk and an important feature of agricultural markets in international agricultural trade. Changes in prices have been shown to have remarkable implications on the allocation of resources, as well as producer and consumer welfare. To this end price volatility may have a negative effect at the microeconomic level of poverty and growth in the developing economies (Aizenman \& Marion, 1993; Ramey \& Ramey, 1995).

Some economists suggest that there is a level of connection between crises and price volatility; firstly, higher price volatility could be leading to an economic crisis (Aizenman \& Pinto, 2005; Acemoglu et al., 2003). Secondly, commodity price volatility may also contribute to governments and farmers household decisions. As argued by Dehn et al. (2005), price risk is one of the most important components of risk faced by households and not solely on earnings. Gilbert (2006) further conducted a study where he showed that agricultural price volatility was higher in the 1970s than in the 1960s, although there was a remarkable decline in the second half of 1980s and the 1990s respectively. It has however maintained a steady growth 
above the level of the 1960s and persisted till date. Overall, it is in view of this high volatility in prices that this study deemed it important to simultaneously examine the export function of cocoa production and determines the effect of price and exchange rate volatility on cocoa export growth in Nigeria. This study may help policymakers in the design of appropriate policies and to help market participants to better accommodate these phenomena (price and exchange rate volatility).

\section{Research Methodology}

In achieving the study's objective, the following information criteria are important for the estimating techniques that were adopted for the study. In addition, this study may suggest policies that can help to mitigate the risk of price volatility.

Scope of the Study, Data and Data Sources: Monthly data from 1970 to 2016 were employed for this study. Data on real Gross Domestic Product (GDP), cocoa output (OUTPUT), the value of cocoa (QXP), exchange rate (EXR), price indexes of cocoa (COCOAP) and consumer price index (CPI) were employed for the econometrics analyses. The data were sourced from the Central Bank of Nigeria's Statistical Bulletin, Annual Report and Statement of Accounts and the Trade Summary published by the National Bureau of Statistics (NBS) and World Bank.

Application of the Export Supply Model for Cocoa: In order to examine the export function of cocoa production in Nigeria, this study follows the view of Mehare and Edriss (2012), where the export supply model for cocoa are presented using the Ordinary Least Square (OLS) method as:

$X_{t}=\alpha+\beta_{1} G D P_{t}+\beta_{2}$ OUTPUT $_{t}+\beta_{3} E_{X} R_{t}+\beta_{4}$ COCOAP $_{t}+\beta_{5} C_{C P}+\varepsilon_{t}$

Where

$\propto$ is the intercept

$\beta_{1}$ to $\beta_{2}$ are coefficients.

$X_{t}$ represents the value of cocoa output exported at time t which is captured by QXP.

$\varepsilon_{t}$ is the error term.

Tests for Unit Root for the OLS Methodology: Several methods can be used to test the stationarity of the data set. However, the common ones are: Augmented Dickey-Fuller (ADF) test and Phillips-Perron (PP) test. In this study, both tests were employed in order to allow for robustness check. The unit root test equation can be presented as:

$y_{t}-\alpha-\beta_{t}=\emptyset_{1}\left(y_{t-1}-\alpha-\beta(t-1)+\varepsilon_{t} \quad \varepsilon_{t} \sim \operatorname{iid}\left(0, \sigma^{2}\right), \quad t=1,2, \ldots \ldots, T\right.$.

Where the deterministic trend is deducted from $y_{t}$. In practice, $\alpha$ and $\beta$ are unknown and have to be estimated. The model can be rewritten as:

$y_{t}=\left(1-\emptyset_{1}\right) \alpha+\emptyset_{1} \beta+\left(1-\emptyset_{1}\right) \beta_{t}+\emptyset_{1} y_{t-1}+\varepsilon_{t}$

Which includes an intercept and a trend that, is

$y_{t}=\alpha^{*}+\beta^{*} t+\emptyset_{1} y_{t-1}+\varepsilon_{t}$.

Where

$\alpha^{*}=\left(1-\emptyset_{1}\right) \alpha+\emptyset_{1} \beta$ and $\beta^{*}=\left(1-\emptyset_{1}\right) \beta$

If, $\left[\emptyset_{1}\right]<1$, the Autoregressive (AR) process has no unit root.

Structural Vector Autoregressive (SVAR) Methodology: In line with the SVAR of Stock and Waston (2005), this study determines the effects of price and exchange rate volatility of cocoa using an SVAR in level. The level SVAR is employed owing to its good economic interpretation that can be derived from its impulse response functions. For example, the Vector Error Correction Model (VECM)'s impulse response assumes that the impact of volatilities is permanent; the level SVAR's impulse response functions allow time and history to determine whether the impact of volatilities is permanent or not (Ramswamy \& Sloek, 1998). In addition, the level SVAR is easy to compute and interpret. These merits, therefore, make it attractive to this study to use the SVAR methodology in this study.

Assuming the Nigerian economy can be given according to the following equation:

$\Omega ¥_{t}=C_{o}+\alpha_{1} ¥_{t-1}+\alpha_{2} ¥_{t-2}+\cdots \ldots . \alpha_{p} ¥_{t-p}+Z \varepsilon_{t}$. 
Where $\Omega$ is a (k by k) matrix that is explaining the immediate relationship amongst the variables employed $¥_{t}$ is a ( $\mathrm{k}$ by 1 ) vector of endogenous variables in which $\left(¥_{t}=¥_{t-1}, ¥_{t-2}, \ldots \ldots . . ¥_{t-p}\right.$ ); $\mathrm{C}_{\mathrm{o}}$ is a (k by 1 ) vector of constants; $\alpha_{1} \ldots . . \alpha_{p}$ are (k by k) matrix of coefficients of endogenous variables; $\mathrm{Z}$ is a (k by k) matrix in which the elements allow for an immediate effect of certain shocks on the endogenous variable; and $\varepsilon_{\mathrm{t}}$ is an error term. Equation 4.3.1 can't be estimated straight way due to the immediate reaction innate in the SVAR system (Enders, 2004). The SVAR integrates feedback since the endogenous variables affect each other, both in the present and the past time of $\Omega ¥_{t}$. Hence, the parameters are unidentified and it is impossible to determine their values (McCoy, 1997). Nevertheless, the figures can be determined by estimating a reduced form SVAR inherent in the equation (Ngalawa \& Viegi, 2001). To do this, we pre-multiplied equation 4.3 .1 by an inverse of $\Omega$ as below:

$\Omega^{-1} \Omega ¥_{t}=\Omega^{-1} C_{o}+\Omega^{-1} \alpha_{1} ¥_{t-1}+\Omega^{-1} \alpha_{2} ¥_{t-2}+\ldots \Omega^{-1} \alpha_{p} ¥_{t-p}+\Omega^{-1} Z \varepsilon_{t}$

This provides:

$Y_{t}=\Omega^{-1} C_{o}+\Omega^{-1} \alpha_{1} ¥ t-1+\Omega^{-1} \alpha_{2} ¥ t-2+\ldots \Omega^{-1} \alpha_{p} ¥_{t-p}+\Omega^{-1} Z \varepsilon_{t}$

However, if we further denote $\Omega^{-1} C_{o}=C, \Omega^{-1} \alpha_{i}=\beta_{i}$ for $i=1 \ldots \ldots$, and $\Omega^{-1} Z \varepsilon_{t}=\mu_{t}$

Therefore, equation (4.3.1) becomes:

$Y_{t}=C+\beta_{1} ¥_{t-1}+\beta_{2} ¥_{t-2}+\cdots \ldots \ldots+\beta_{p} ¥_{t-p}+\mu_{t} \ldots$

The change between equations (4.3.1) and (4.3.4) is that "the first is a long-form SVAR where all variables have an immediate effect on each other, while the second is a reduced form SVAR, where no variable has an immediate effect on each other in the model" Enders (2004). More so, $\mu_{t}$ is a composite of the volatility in $Y_{t}$ as further revealed by Enders (2004).

Matrix Formation and the Imposition of Restrictions on the SVAR Methodology: Following the view of Buckle et al. (2007), the SVAR approach involves the imposition of restrictions on the parameters to derive a sound economic structure. The restrictions limit the responsiveness to variations that creates volatilities in the system that satisfies the expected sign in the reactions of main variables in the model (see Dungey \& Fry, $2007 ; 2009)$. The primitive restriction ranges from $f_{21}$ to $f_{65}$ that capture immediate responses in the system, while the " 0 " captures the sluggish response in the SVAR relationships. Based on equation 4.3.5, a total of seventeen (17) zero restrictions were imposed on matrix A on the left hand side which allows matrix covariance to be restricted and the diagonal is controlled to be "1". On the other hand, the matrix B in the right-hand is the diagonal matrix that is uncorrelated. In total, six by six matrices were modeled for this study, using the short run structural restrictions AB-model of Amisano and Gianini (1997), as presented in equation 4.3.5.

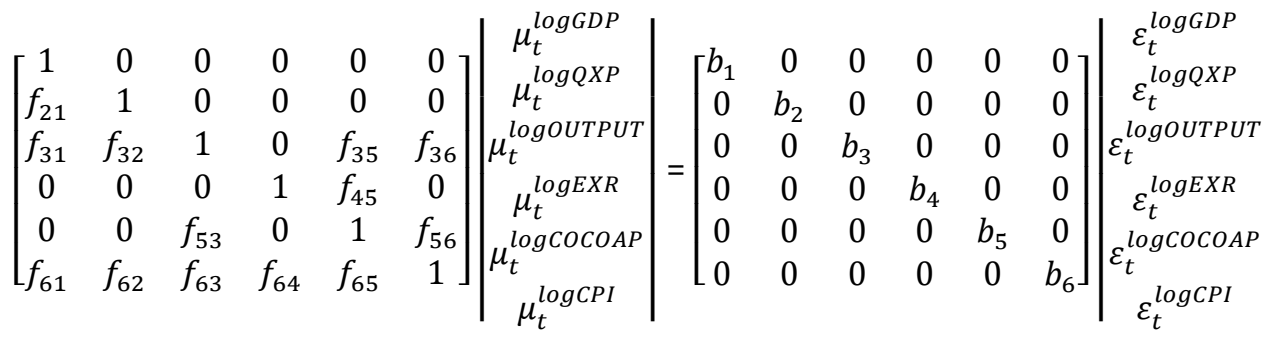

The matrix above in equation 3.3.5 is a 6 by 6 SVAR matrixes capturing the 6 -variables used in the model where the $\mu_{t}^{\log G D P}, \mu_{t}^{\log Q X P}, \mu_{t}^{\log O U T P U T}, \mu_{t}^{\log E X R}, \mu_{t}^{\log C O C O A P}$ and $\mu_{t}^{\log C P I}$ are the vectors in the reduced form and $\varepsilon_{t}^{\log G D P}, \varepsilon_{t}^{\log Q X P}, \varepsilon_{t}^{\log }{ }^{\text {loUTPUT }}, \varepsilon_{t}^{\log E X R}, \varepsilon_{t}^{\log \operatorname{loCOAP}}$ and $\varepsilon_{t}^{\log C P I}$ are the structural shocks linked to the corresponding equations that captures volatility in the model. Conversely, the way variables affect each other depends on their location in the matrix. The variables are ordered following economic principle of Pesaran and Shin (1998) to prevent arbitrary ordering. For example, row 1 measures the effect of real GDP on the economy. It shows that GDP only responds instantaneously to its own value, while equations 2 and 3 indicate the value of cocoa and cocoa output. The value of cocoa (QXP) responds to GDP and its own lagged value, while $f_{31}$ and $f_{32}$ indicates that the cocoa output reacts instantaneously to GDP and QXP. Equation 4 is the exchange rate (EXR) which only shows the immediate reaction of cocoa price, as shown by $f_{45}$ while equations 5 and 6 define the international and domestic goods market price. The COCOAP responds instantaneously to OUTPUT and prices (CPI), while CPI responds instantaneously to all the variables (GDP, QXP, OUTPUT, EXR and COCOAP). 
The Lag Selection: The lag selection also refers to the lag length determination that deals with the time between exchange rate volatility, prices and the export growth of cocoa in Nigeria. The monthly data are being employed in this study, in order to have a better estimate with a large degree of freedom. Since the data are monthly, the choice of lag selections is drawn from an optimum lags order using the Akaike Information Criterion (AIC), Schwarz Information Criterion (SIC) and Hannan-Quinn Criterion (HQC). These three types of lag orders are the most commonly used in literature, to select the minimum likely lag length. The basic formula for determining the lag length according to Green (2002) is given as:

$\operatorname{SIC}_{P \max }=\left[12\left(\frac{T}{100}\right)^{1 / 4}\right]$

\section{Empirical Results and Data Analysis}

This part contains the interpretation of the results obtained from the methodologies employed. The $O L S$ and SVAR methodologies were employed to determine the impact of volatilities on the export function of cocoa production in Nigeria. The results obtained from these procedures are given below:

Unit Root Testing Result: For the OLS methodology, this study tested for unit root using the dynamic version of ADF and PP-Fisher at constant and constant plus trend in order to prevent spurious results.

Table 1: ADF Unit Root Tests

\begin{tabular}{|c|c|c|c|c|c|c|}
\hline \multirow[t]{2}{*}{ Variables } & \multicolumn{3}{|c|}{ ADF-Fisher Unit root-test (Constant) } & \multicolumn{3}{|c|}{ ADF Unit root-test (Constant, Linear Trend) } \\
\hline & $\begin{array}{l}\text { Order of } \\
\text { integration }\end{array}$ & $t^{*}$ Statistics & P Value & $\begin{array}{l}\text { Order of } \\
\text { integration }\end{array}$ & $t^{*}$ Statistics & P-Value \\
\hline GDP & $\mathrm{I}(1)$ & -2.868768 & $0.0498^{* * *}$ & $\mathrm{I}(1)$ & -4.188378 & $0.0050^{* * *}$ \\
\hline QXP & $\mathrm{I}(1)$ & -3.607183 & $0.0060^{* * *}$ & $\mathrm{I}(1)$ & -4.320073 & $0.0031^{* * *}$ \\
\hline OUTPUT & $\mathrm{I}(1)$ & -5.520343 & $0.0000^{* * *}$ & $\mathrm{I}(1)$ & -5.651736 & $0.0000^{* * *}$ \\
\hline EXR & $\mathrm{I}(1)$ & -4.725457 & $0.0001^{* * *}$ & $\mathrm{I}(1)$ & -4.932052 & $0.0003^{* * *}$ \\
\hline СOCOAP & $\mathrm{I}(1)$ & -4.163242 & $0.0008^{* * *}$ & $\mathrm{I}(1)$ & -5.213600 & $0.0001^{* * *}$ \\
\hline CPI & $\mathrm{I}(1)$ & -6.881738 & $0.0000^{* * *}$ & $\mathrm{I}(1)$ & -6.877595 & $0.0000^{* * *}$ \\
\hline
\end{tabular}

“***” “**” and "*” represent statistical significance at $1 \%, 5 \%$, and $10 \%$ respectively.

Table 2: PP- Fisher Chi-Square Unit Root Tests

Variables PP Unit-root test (Constant) PP Unit-root test (Constant, Linear Trend)

\begin{tabular}{lllllll} 
& $\begin{array}{l}\text { Order of } \\
\text { integration }\end{array}$ & $\mathbf{t}^{*}$ Statistics & P Value & $\begin{array}{l}\text { Order of } \\
\text { integration }\end{array}$ & $\mathbf{t}^{*}$ Statistics & P-Value \\
\hline GDP & I(1) & -14.84498 & $0.0000^{* * *}$ & $\mathrm{I}(1)$ & -16.30299 & $0.0000^{* * *}$ \\
QXP & $\mathrm{I}(1)$ & -16.72694 & $0.0000^{* * *}$ & $\mathrm{I}(1)$ & -17.23177 & $0.0000^{* * *}$ \\
OUTPUT & $\mathrm{I}(1)$ & -17.94294 & $0.0000^{* * *}$ & $\mathrm{I}(1)$ & -17.99560 & $0.0000^{* * *}$ \\
EXR & $\mathrm{I}(1)$ & -17.63672 & $0.0000^{* * *}$ & $\mathrm{I}(1)$ & -17.69894 & $0.0000^{* * *}$ \\
COCOAP & $\mathrm{I}(1)$ & -17.00294 & $0.0000^{* * *}$ & $\mathrm{I}(1)$ & -17.11847 & $0.0000^{* * *}$ \\
CPI & $\mathrm{I}(1)$ & -17.18908 & $0.0000^{* * *}$ & $\mathrm{I}(1)$ & -17.18393 & $0.0000^{* * *}$ \\
\hline
\end{tabular}

“***" “**” and "*” represent statistical significance at $1 \%, 5 \%$, and $10 \%$ respectively.

Table 3: Descriptive Analysis

\begin{tabular}{llccccc}
\hline & DQXP & DGDP & DOUTPUT & DEXR & DCOCOAP & DCPI \\
\hline Mean & 339016.0 & 557.0801 & 0.058477 & 0.313878 & 910.9238 & 0.011055 \\
Median & 1236.861 & 440.9583 & 0.388889 & 0.005278 & 3.625000 & 0.054924 \\
Maximum & 21576317 & 7858.840 & 70.84375 & 27.64293 & 79205.80 & 17.65566 \\
Minimum & -9281561. & -7070.157 & -78.72106 & -11.66076 & -38721.41 & -18.12400 \\
Std. Dev. & 1422016. & 1092.513 & 8.052284 & 1.742236 & 5641.838 & 2.153193 \\
Skewness & 6.778065 & -0.408666 & -0.736893 & 7.500738 & 6.014034 & -0.293789 \\
Kurtosis & 106.1510 & 14.66651 & 56.61547 & 132.5890 & 90.35573 & 34.25214 \\
\hline
\end{tabular}




\begin{tabular}{lllllll}
\hline Jarque-Bera & 232262.9 & 2934.974 & 61731.14 & 365185.5 & 166853.5 & 20965.68 \\
Probability & 0.000000 & 0.000000 & 0.000000 & 0.000000 & 0.000000 & 0.000000 \\
\hline
\end{tabular}

The benefits of using these approaches (ADF and PP) are to relate and corroborate the results in order to ensure consistency (See Moon \& Perron, 2004; Demetriades \& Fielding, 2012; Ishibashi, 2012; Frimpong, 2012). According to the results derived from the analysis, all the variables were non-stationary at levels I(0), but were all stationary at first difference I(1). The results are presented in Tables 1 and 2 . The P-value shows that at $1 \%$, all the variables are statistically significant and have no unit roots. Table 3 shows the descriptive analysis of all the activities about the export function for cocoa production (QXP) and determines the effect of price and exchange rate volatility on cocoa export in Nigeria. All the variables appear in differenced form. The mean reveals the average value of all the data employed. The OUTPUT, EXR and CPI show that the mean falls in the lower value of the distribution, while QXP, GDP and COCOAP show that the mean falls in the upper value of the distribution. The standard deviation values in the table show the rate at which the variables deviated from their respective average. The kurtosis reveals that all the variables were leptokurtic because the kurtosis coefficients are all positive. The Jarque-Bera and probability values show that QXP, GDP, OUTPUT, EXR, COCOAP and CPI are not normally distributed, but statistically significant in examining the export function for cocoa production (QXP) and determine the effect of price and exchange rate volatility on cocoa export in Nigeria.

The OLS Methodology Results: This is in line with equation 4.1.1, that is set out to determine the use of export supply model for cocoa production in Nigeria. Table 4 shows the results obtained from the regression analysis of export supply model for cocoa production in Nigeria. The final result shows that there exists a positive relationship between the value of cocoa production, as well as the Gross Domestic Product, cocoa output, exchange rate, cocoa price and the general price level. Given the result, all the variables are statistically significant at 5\%, in determining the variations in QXP. We have enough evidence to conclude that all the independent variables in the model have a significant impact on the dependent variables, hence, determine the value of export supply model for cocoa production in Nigeria.

Table 4: The OLS Results

\begin{tabular}{llllll}
\hline Variable & Coefficient & Std. Error & t-Statistic & Prob. & \\
\hline C & 73979.51 & 21114.09 & 3.503799 & 0.0005 & R2=0.91 \\
DGDP & 60.23924 & 18.81322 & 3.201963 & 0.0015 & F-stat.= 1111.414 \\
DOUTPUT & 13373.14 & 2690.043 & 4.971349 & 0.0000 & DW=0.461509 \\
DEXR & 63700.65 & 12983.18 & 4.906398 & 0.0000 & \\
DCOCOAP & 231.0803 & 3.647659 & 63.35030 & 0.0000 & \\
DCPI & 18597.90 & 8959.798 & 2.075705 & 0.0384 & \\
\hline “***, “**" and "*” represent statistical significance at 1\%, 5\%, and 10\% respectively. &
\end{tabular}

The $\mathrm{R}^{2}$ helps to determine the goodness of fit of the parameter estimates. It shows the percentage of the total variation of the dependent variable that can be explained by the change of the independent variables. The higher the $\mathrm{R}^{2}$ the greater the percentage of the variations of the dependent variable, that is explained by the regression line. The closer the $\mathrm{R}^{2}$ is to zero, the worse the fitness of the model. Therefore, the $\mathrm{R}^{2}$ of $91 \%$ shows that the model is of good fit. Furthermore, the F-statistics allows us to test for the statistical validity and reliability of the regression equation, so as to serve as a base for the accurate economic forecast. The overall result shows that the estimates are statistically different from zero and have a degree of influence on cocoa export. The Durbin-Watson test reveals 0.461509, which shows no autocorrelation detected in the model, as revealed by the P-value of all the variables.

Structural Breakpoint Test: Following Hanson (2002), this study tests for structural breaks using the chow test. The result shows no evidence for the study to reject the null hypothesis of no breaks at the specified breakpoints. This implies that there is no reason to think that anything abrupt has occurred or lack of continuity during the estimated period. The choice period (2008:01) for the chow breakpoint is due to the fact that the period accounts for the time of global recession when Nigeria's economy was badly affected. 
However, the National Bureau of Statistics (NBS) revealed that Nigeria exited recession in the third and fourth quarters of 2008 .

Table 5: Structural Breakpoint Test Chow Breakpoint Test: 2008M01

\begin{tabular}{llll} 
F-statistic & 1491.209 & Prob. F(6,503) & 0.2040 \\
Log-likelihood ratio & 1510.601 & Prob. Chi-Square(6) & 0.1100 \\
Wald Statistic & 8947.251 & Prob. Chi-Square(6) & 0.3300 \\
\hline
\end{tabular}

Diagnostic Tests: In line with Kutu et al. (2017), this study conducts a serial correlation test, normality test and heteroscedasticity test. The hypotheses for the benchmark that are tested are:

H0: $\alpha=1$, no serial correlation, no heteroskedasticity and normality of the model

$H 1: \alpha \neq 1$, there is serial correlation, heteroskedasticity and non-normality of the model.

Based on the results in Table 6, we accept that there is no serial correlation (similarity between observations) in the model. In addition, Table 7 reveals that the model is free from heteroscedasticity. These results have shown that our model is consistent in examining the export function for cocoa production and determines the effect of price and exchange rate volatility on cocoa export in Nigeria. Finally, Figure 1 shows the normality test for the OLS model. The Jarque-Bera statistics indicate non-normality of most of the series. This is not a good sign for the model. However, researchers term it as a "weaker sign" and do not constitute a risk to the model and do not affect forecasting accuracy (see Ngalawa \& Kutu, 2017; Bala \& Asemota, 2013; Goyal \& Arora, 2010).

Table 6: Serial Correlation Test Breusch-Godfrey Serial Correlation LM Test:

$\begin{array}{llll}\text { F-statistic } & 518.7555 & \text { Prob. F(2,507) } & 0.3244 \\ \text { Obs*R-squared } & 345.9465 & \text { Prob.Chi-Square(2) } & 0.8161\end{array}$

Table 7: Hetoroskedasticity Test

Heteroskedasticity Test: Breusch-Pagan-Godfrey

$\begin{array}{llll}\text { F-statistic } & 40.90593 & \text { Prob. F(5,509) } & 0.2092 \\ \text { Obs*R-squared } & 147.6221 & \text { Prob. Chi-Square(5) } & 0.4810\end{array}$

\section{Figure 1: Normality Test}

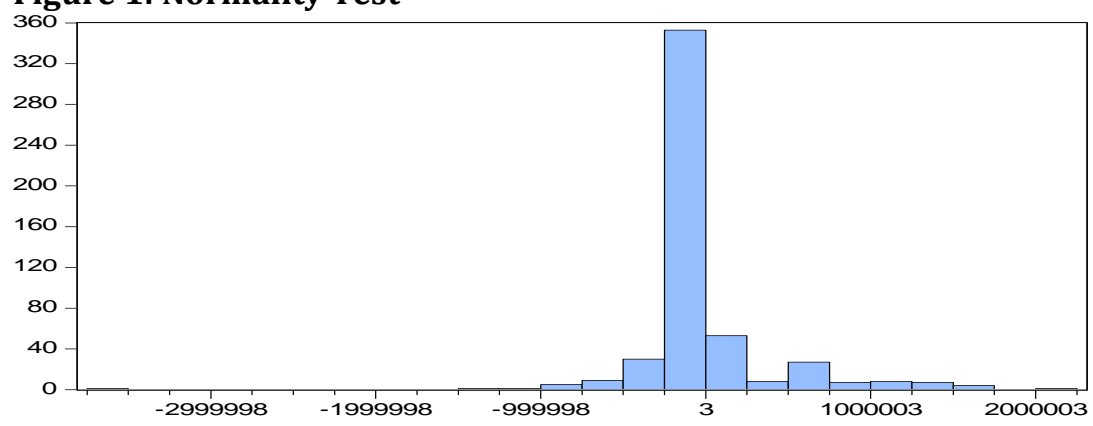

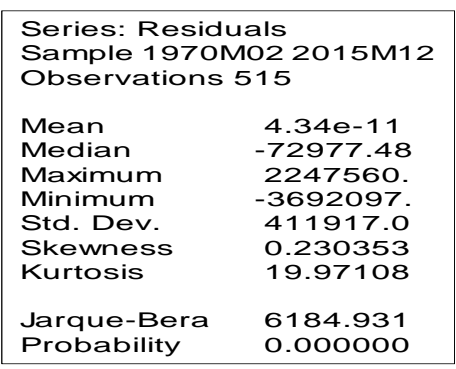

Sample 1070 Mo

Observations 515

4.34e-11

$-72977.48$

Maximum 2247560 .

Std Dev $\quad 4692097$

Skewness

Jarque-Bera 6184931 Probability

\section{The SVAR Methodology Results}

The Lag Selection: Given the results in Table 8, the AIC, FPE and LR tests suggest 4-lags SC suggests 2-lags and the HQ suggests 3-lags for the SVAR. However, to reach a conclusion and choose the optimum lag, we choose the AIC, as it gives the minimum number, justifying the selection of 4-lags for the study. More so, the 
choice of the 4-lag length for this study offers a dynamic result as it is devoid of shortening the estimation sample and does not allow serial correlation in the residuals. This choice is guided by Sharifi-Renani (2010) and Elbourne (2008).

\section{Table 8: SVAR Lag Order Selection Criteria}

\begin{tabular}{lllllll}
\hline Lag & Log L & LR & FPE & AIC & SC & HQ \\
\hline 0 & -1027.890 & NA & $2.65 \mathrm{e}-06$ & 4.185789 & 4.236832 & 4.205829 \\
1 & 6025.513 & 13906.91 & $1.21 \mathrm{e}-18$ & -24.22475 & -23.86745 & -24.08447 \\
2 & 6261.124 & 458.8230 & $5.41 \mathrm{e}-19$ & -25.03289 & $-24.36933^{*}$ & -24.77238 \\
3 & 6341.449 & 154.4703 & $4.53 \mathrm{e}-19$ & -25.21234 & -24.24253 & $-24.83159^{*}$ \\
4 & 6378.703 & $70.73784^{*}$ & $4.50 \mathrm{e}-19^{*}$ & $-25.21742^{*}$ & -23.94135 & -24.71644 \\
5 & 6398.122 & 36.39974 & $4.82 \mathrm{e}-19$ & -25.15029 & -23.56796 & -24.52907 \\
6 & 6409.743 & 21.50206 & $5.32 \mathrm{e}-19$ & -25.05159 & -23.16300 & -24.31013 \\
7 & 6418.406 & 15.81715 & $5.95 \mathrm{e}-19$ & -24.94091 & -22.74607 & -24.07922 \\
8 & 6428.242 & 17.72138 & $6.62 \mathrm{e}-19$ & -24.83499 & -22.33388 & -23.85305 \\
\hline
\end{tabular}

The Impulse Response Functions of the SVAR: In line with equation 4.3.4, we estimate the impulse response function for cocoa production, exchange volatility and prices in Nigeria. The impulse response is built for the volatilities to all the variables in the model. It allows us to detect the response of the economy to volatility on cocoa export, the relationships between cocoa producer price volatility and other economic indicators and in addition, the relationship between price and exchange rate volatility. The volatility on variables in the model is on 12-month periods to determine the response of the economy to the volatilities on export growth of cocoa in Nigeria.

The Impulse Response of GDP: On the impulse response function graphs, the horizontal axis measures the time scale for 12-months. The black line that divides the box into two is the zero-degree line. The two red lines serve as a $5 \%$ confidence interval that defines the significance/insignificance impact when volatility is given in the system. Below the zero-degree line is a negative response, while above it is a positive response. When both lines are either above or below the zero-degree line, it shows a significant impact (see the response of Log GDP to Log GDP from the 1-month to the 7-month), but when one red line is above the zerodegree line and the other is below it, it indicates an insignificant impact (see response of GDP to QXP, OUTPUT and EXR). Based on this understanding, much of the significant volatility to real GDP in Graph 1 is caused by the shocks of GDP to its own value and prices, while volatility from other variables have an insignificant impact on the GDP. The volatility to cocoa price has a positive long run impact from the 7-month to the 12-month, while the volatility in the general price level negatively impacts on the GDP at the same time.

Graph 1: Response of GDP to Shocks GDP, QXP, OUTPUT, EXR, COCOAP and CPI

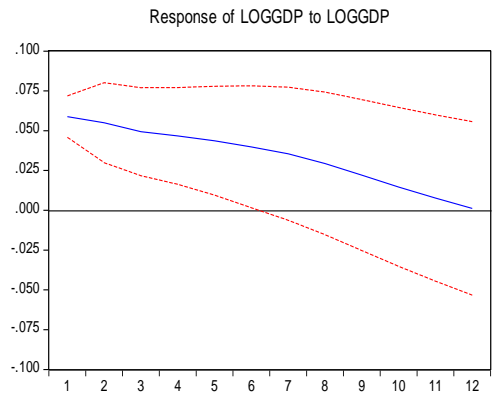

Response of LOGGDP to LOGEXR

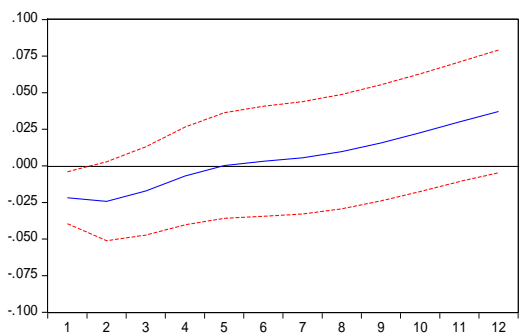

Response of LOGGDP to LOGQXP

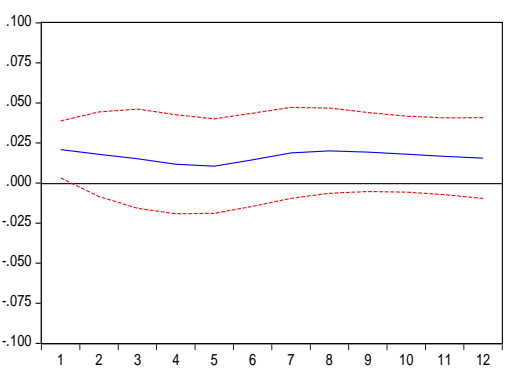

Response of LOGGDP to LOGCOCOAP

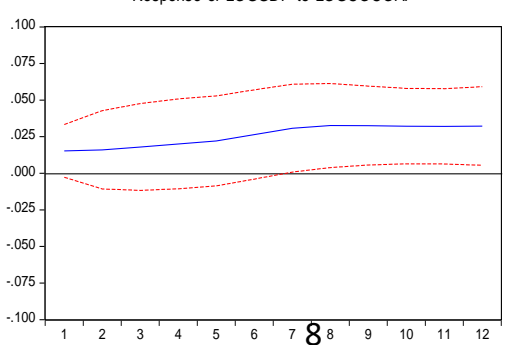

Response of LOGGDP to LOGOUTPUT

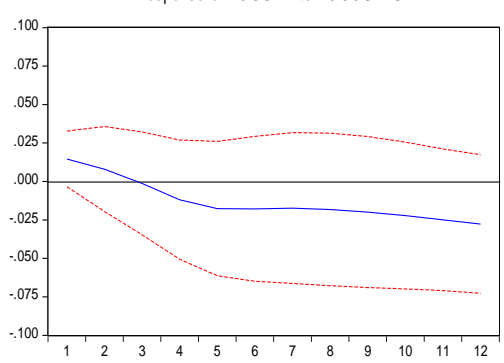

Response of LOGGDP to LOGCP

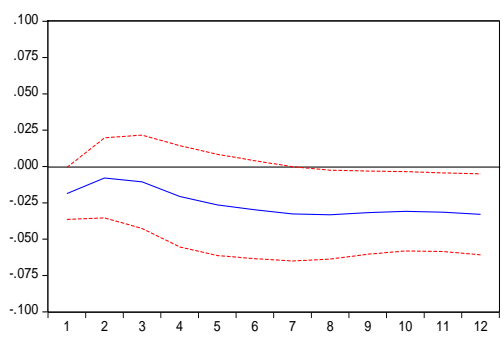




\section{Journal of Economics and Behavioral Studies (ISSN: 2220-6140) \\ Vol. 11, No. 2, pp. 1-13, April 2019}

The Impulse Response of QXP: Graph 2 shows the response of the value of cocoa (QXP) to volatility from other variables. The results reveal that its own shocks, output, exchange rate, cocoa price and general price level have a significant impact, while the GDP remains insignificant for the entire months. However, the volatilities to exchange rate account for the greater volatility (positively significant for the entire months), to the value of cocoa exported as against cocoa output (negative significant impact from 2-month to 5-month), cocoa price (significant between 3-month to 9-month) and general prices (negatively significant from 4month to 8-month).

\section{Graph 2: Response of QXP to Shocks GDP, QXP, OUTPUT, EXR, COCOAP and CPI}
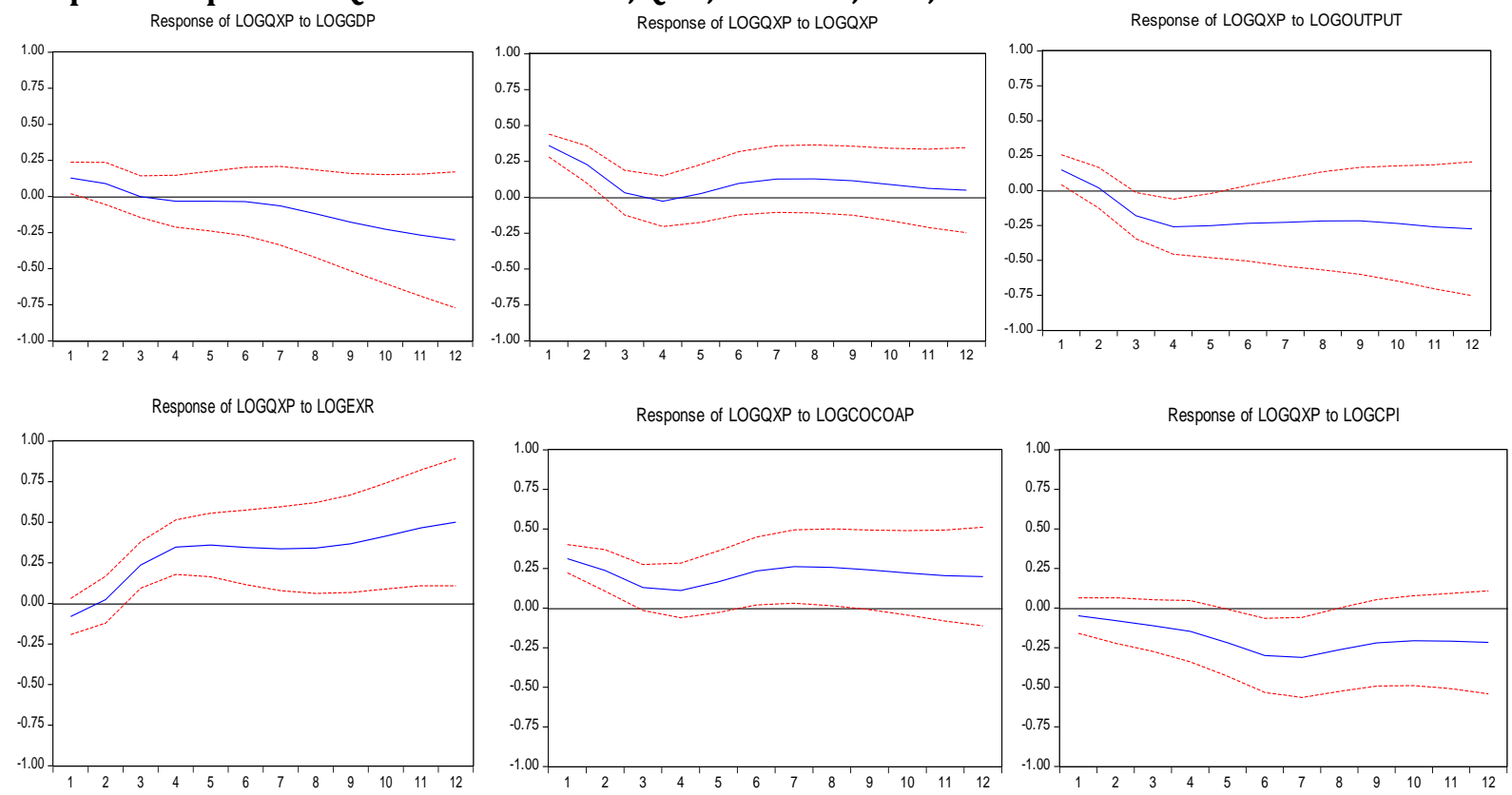

The Impulse Response of Output: On cocoa output, it is only the volatility in exchange rate that shows an upward significant impact from the 1-month to the 2-month and subsequently turned insignificant, hence, trend steadily on a positive note for the remaining months, while volatilities to all other variables do not cause a significant volatility to cocoa output.

\section{Graph 3: Response of OUTPUT to Shocks GDP, QXP, OUTPUT, EXR, COCOAP and CPI}
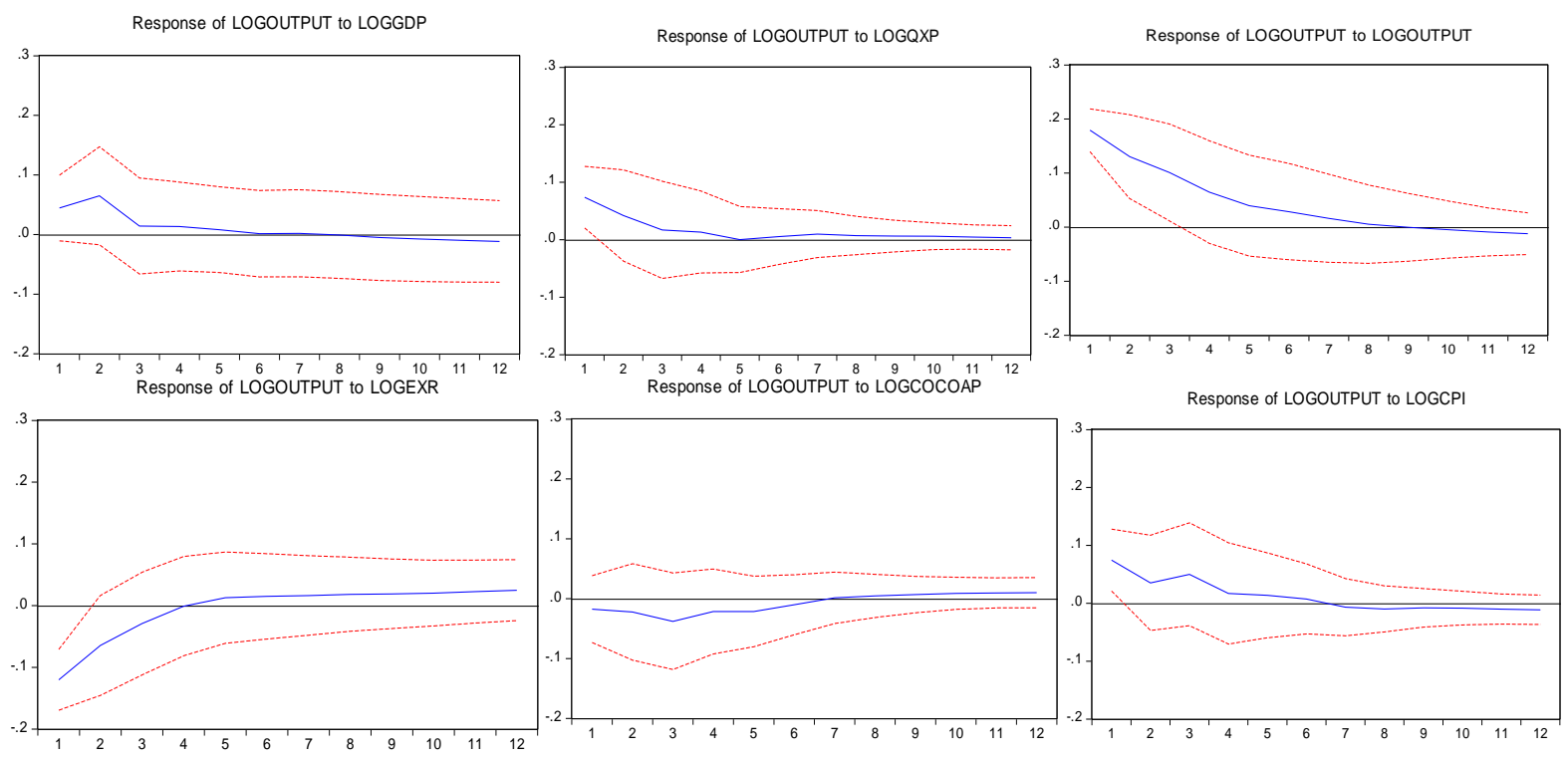


\section{Journal of Economics and Behavioral Studies (ISSN: 2220-6140) \\ Vol. 11, No. 2, pp. 1-13, April 2019}

The Impulse Response of EXR: The result on the exchange rate exhibits similar but different response as shocks from GDP and OUTPUT. It shows a significant impact in causing volatility from the 1-month to the 2month. The volatilities to general price level significantly cause volatility in exchange rate from the 2-month to the 5-month, which is from its own shock (response of log EXR to log EXR) and accounts for much of the volatilities. It remains positively significant for the entire analysed period.

\section{Graph 4: Response of EXR to Shocks GDP, QXP, OUTPUT, EXR, COCOAP and CPI}
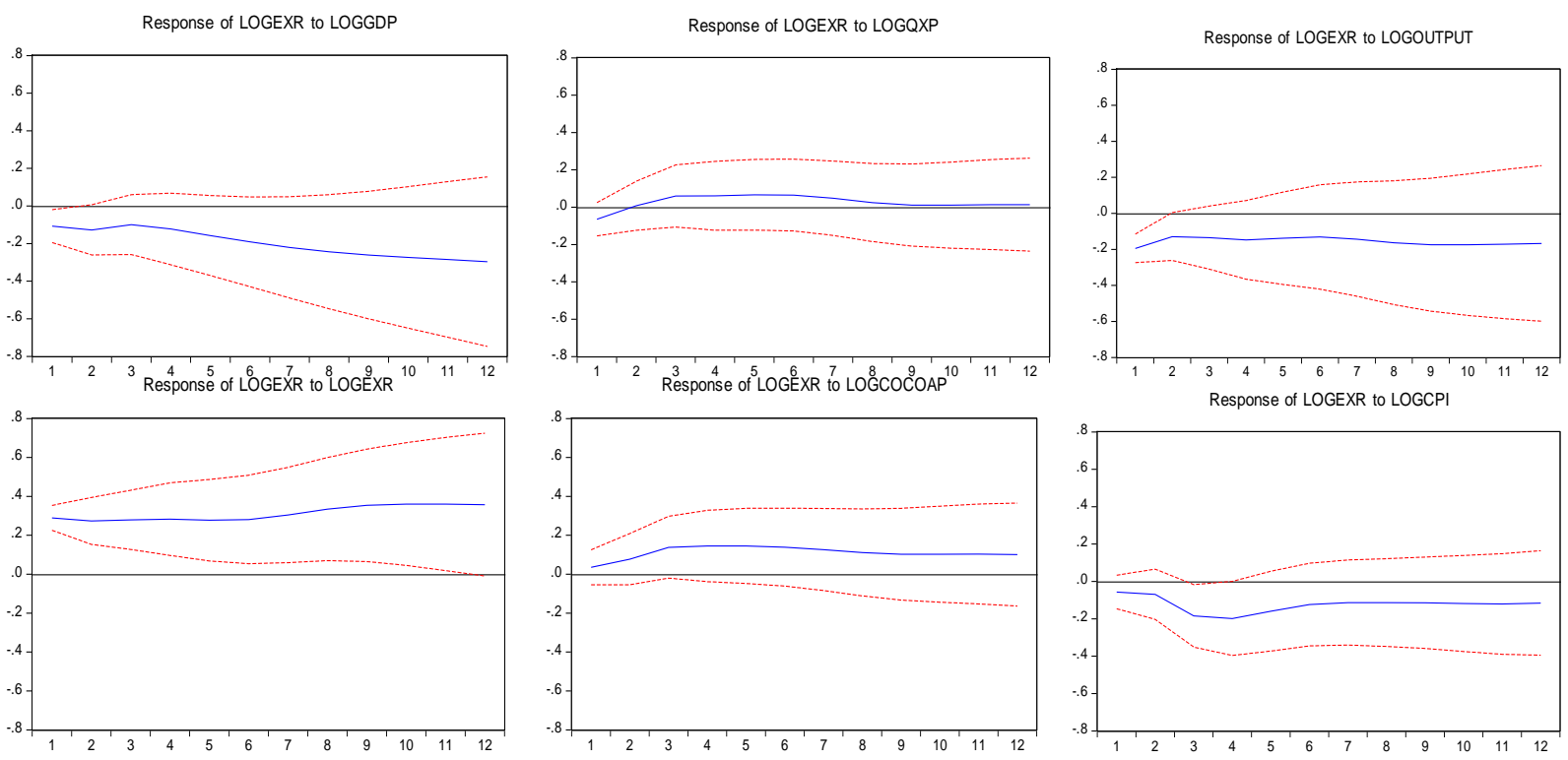

The Impulse Response of COCOAP: In Graph 5, the shocks from GDP do not have a significant impact on cocoa price for the whole months, while shocks to value of cocoa only have a significant impact from the 1-2 months. The volatilities to output negatively cause volatility in cocoa price from the $2-5$ months. The volatilities to exchange rate show a great impact from the 2-month to the 12-month before it dies off, causing volatility in cocoa price. In addition, the general price level also has a negative significant impact on cocoa price from the 1-month to the 8-month.

\section{Graph 5: Response of COCOAP to Shocks GDP, QXP, OUTPUT, EXR, COCOAP and CPI}
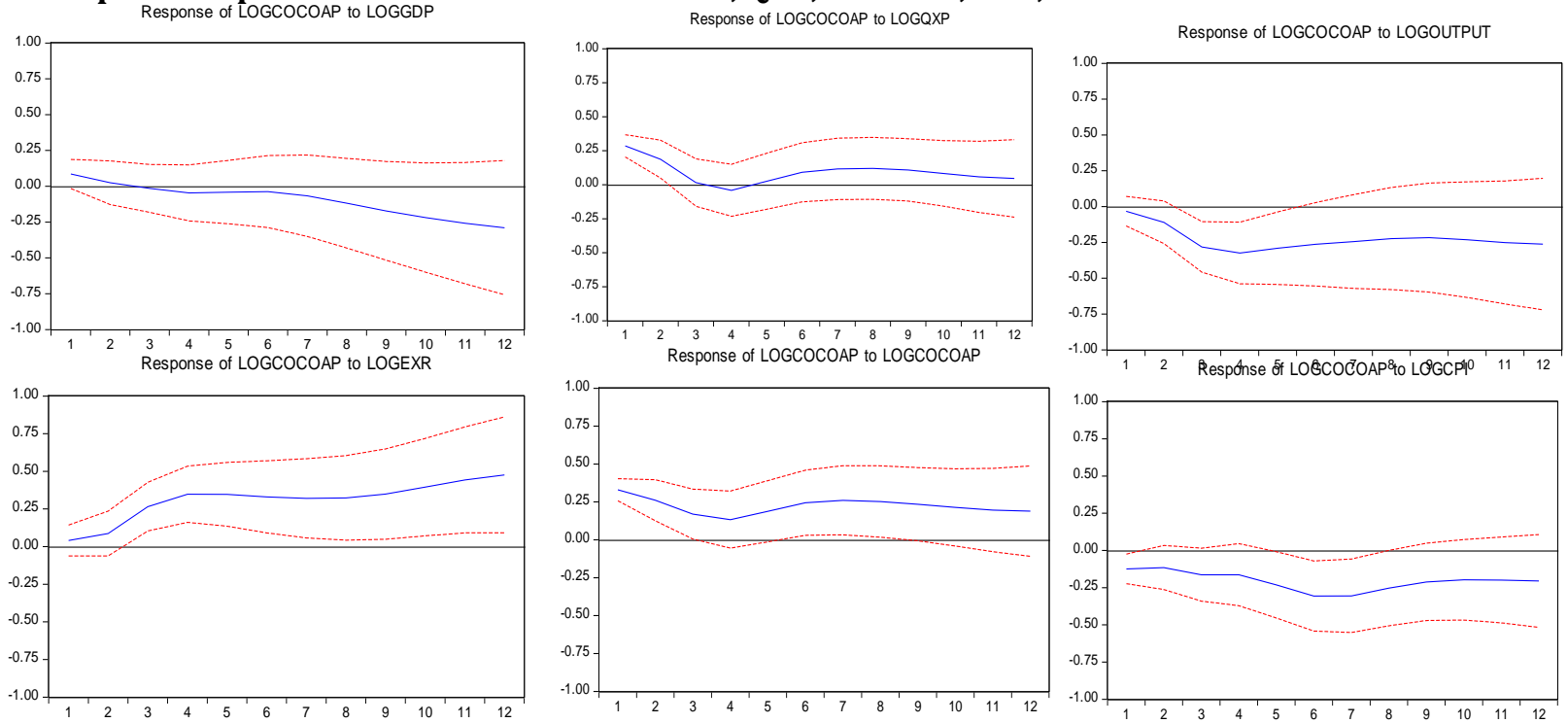
The Impulse Response of CPI: The response of the general price level (CPI) from GDP, QXP and EXR does not show any significant impact on the general price level for the whole months, while shocks to output and cocoa price only have a significant impact in the 1-month in causing volatility in the general price level. The volatility in output positively reduces prices, while cocoa price negatively increases prices. This shows that volatility in both cocoa output production and cocoa price have an impact on general price level in the economy, though within a short period of time.
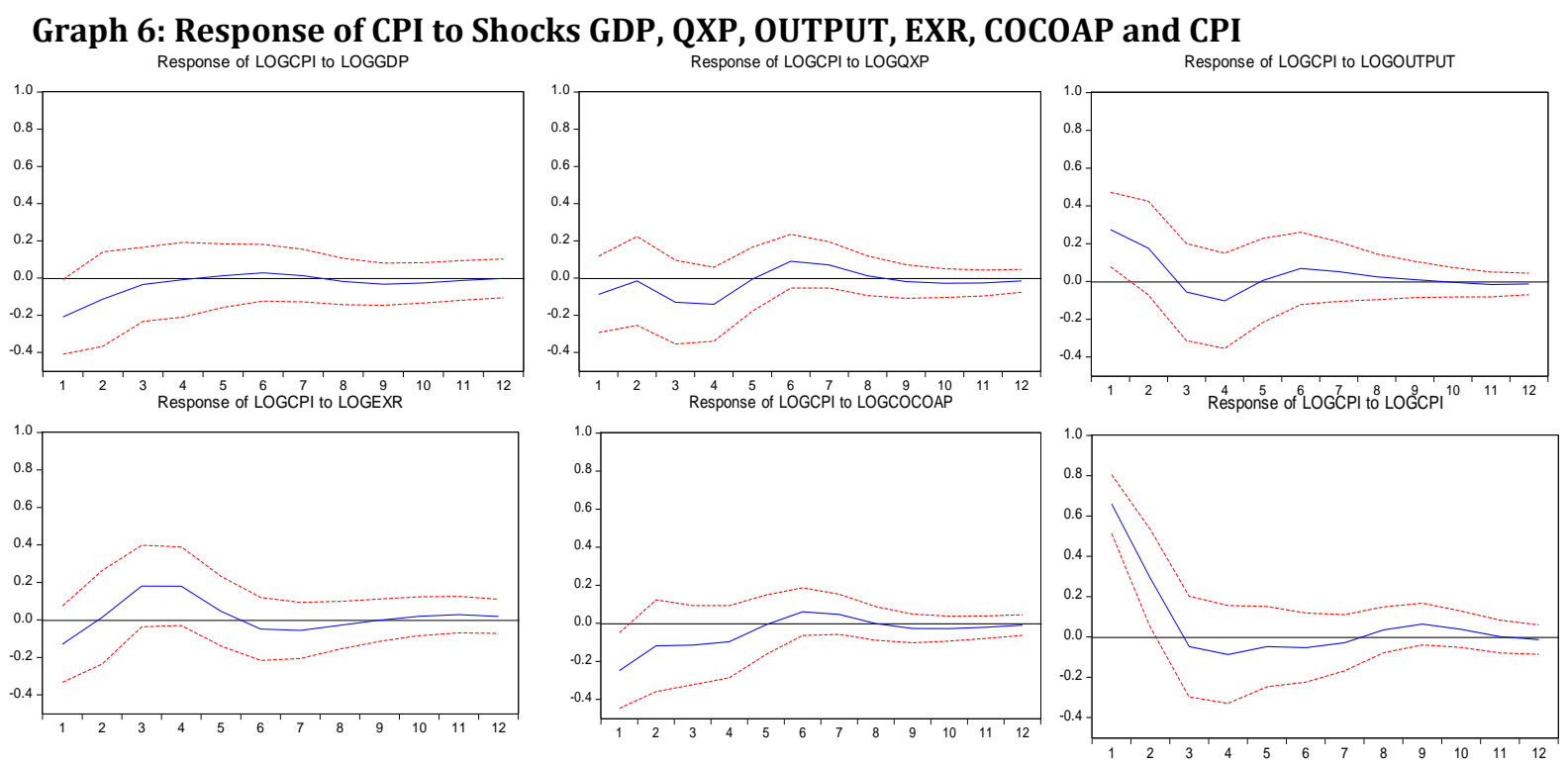

Summary of the Findings with Empirical Comparisons in Nigeria: The aim of this study was to examine the export function of cocoa production and determines the effect of price and exchange rate volatility on cocoa export in Nigeria. After estimating the $O L S$ and SVAR equations, the estimated model passes several residual diagnostic checks including unit root test, lag selections, structural breakpoints test, structural imposition of restrictions and orthogonalised impulse responses analyses. Firstly, the OLS results for the exports supply model of cocoa showed that all the variables were significant in determining the impacts of the value of cocoa production in Nigeria. The price of cocoa on the international market and the value of exchange rates play a significant role on cocoa exports growth in Nigeria. This is in line with Onoja et al. (2012) who carried a study on "the profitability and yield determinants in Nigeria cocoa farm". They recommended that cocoa farming be encouraged to create jobs and reduce poverty, as well as microfinance banks and agricultural agencies to provide farmers with access to credit. Farmers need to be trained on the most effective ways of production to guarantee sustainable cocoa production in Nigeria.

In addition, the results are in line with Verter and Bečvářová (2014) who used the Johansen cointegration and OLS regression methods to analyzed cocoa export in Nigeria. Finally, the OLS results provide a positive relationship between cocoa export and cocoa prices, exchange rates and quantity of cocoa export (significant at 5\%). Likewise, the SVAR analysis shows that much of the results from the impulse response graphs on the volatility to GDP are from the global price of cocoa on the international market. A rise in the price of cocoa will increase cocoa production and export growth in Nigeria. This view supports Idowu et al. (2007) who showed that the significant rise in the total cocoa output production can be attained through a combination of a sustained increase in real producer price, local currency stability and real supply of chemical fertilizer. Additionally, the response of the value of cocoa production shows that the volatilities from the output, exchange rate, cocoa price and general price level have a significant impact, while the GDP remains insignificant for the whole months. The result reveals that the volatilities to exchange rate accounts for the greater volatility (positively significant for the entire months) to the value of cocoa exported as against other variables in the model. This echoes Abolagba et al.'s (2010) findings which showed that the Naira exchange rate volatility reduced non-oil exports by $3.65 \%$, while the US dollar volatility increased export of non-oil (cocoa inclusive) in Nigeria. 
However, for the impulse response analysis of cocoa output, only the volatility of exchange rate shows a significant impact. This finding reflects the view of Nwachuku et al. (2010) who revealed that world export volume, exchange rates and cocoa output were determinants of cocoa export in Nigeria. Overall, the results from this study concur with Essien et al. (n.d) and Adeyeye (2012) that the exchange rate and prices are very crucial to the export growth of cocoa in Nigeria. This is because the price of cocoa is still exogenously determined from the world market, hence, both forces of demand and supply greatly impact on cocoa output growth. The exchange rate has impacted positively on cocoa export in Nigeria; hence, as a policy recommendation, there should be a free market determination of exchange rate for export of cocoa in Nigeria. The repeated intervention by the International Monetary Fund (IMF) 2004 should be discouraged, as it will only increase poverty and reduce output in the country. A weaker exchange rate of the naira will lead to an increase in prices domestically, which can propagate to other sectors of the economy (especially on agricultural products). On the other hand, a stronger exchange rate of naira will reduce prices domestically, and later stabilize the exchange rates and increase cocoa output growth. Finally, as a policy guide, it is recommended that the forces of demand and supply should be allowed to fully determine the value of exchange rates in Nigeria.

\section{References}

Abang, S. O. \& Ndifon, H. M. (2002). Analysis of world cocoa production trends and their production share coefficients (1975-1996). Nigeria Agricultural Journal, 33(1), 10-16.

Abolagba, E. O., Onyekwere, N. C., Agbonkpolor, B. N. \& Umar, H. Y. (2010). Determinants of agricultural exports. Journal of Human Ecology, 29(3), 181.

Acemoglu, D., Johnson, S., Robinson, J. \& Thaicharoen, Y. (2003). Institutional causes, macroeconomic symptoms: volatility, crises and growth. Journal of monetary economics, 50(1), 49-123.

Adeyeye, C. T. (2012). Cocoa Production and Price Stability: An Industrial Relations Perspective. Accessed on, $1(10)$.

Adubi, A. A. \& Okunmadewa, F. (1999). Price, exchange rate volatility and Nigeria's agricultural trade flows: A dynamic analysis (No. RP_087). African Economic Research Consortium.

Aizenman, J. \& Marion, N. P. (1993). Policy uncertainty, persistence and growth*. Review of international economics, 1(2), 145-163.

Aizenman, J. \& Pinto, B. (Eds.). (2005). Managing Economic Volatility and Crises: A Practitioner's Guide. Cambridge University Press.

Aliyu, S. U. R. (2008). Exchange rate volatility and export trade in Nigeria: an empirical investigation. Applied Financial Economics, 20(13), 1071-1084.

Amisano, G. \& Giannini, C. C. (1997). Topics in structural VAR econometrics.

Babula, R. A., Ruppel, F. J. \& Bessler, D. A. (1995). US corn exports: the role of the exchange rate. Agricultural Economics, 13(2), 75-88.

Bala, D. A. \& Asemota, J. O. (2013). Exchange-rates volatility in Nigeria: Application of GARCH models with exogenous break. CBN Journal of Applied Statistics, 4(1), 89-116.

Bradshaw, G. W. \& Orden, D. (1990). Granger causality from the exchange rate to agricultural prices and export sales. Western Journal of Agricultural Economics, 100-110.

Braun, J. V. \& Tadesse, G. (2012). Global food price volatility and spikes: an overview of costs, causes, and solutions. ZEF-Discussion Papers on Development Policy, (161).

Buckle, R. A., Kim, K., Kirkham, H., McLellan, N. \& Sharma, J. (2007). A structural VAR business cycle model for a volatile small open economy. Economic Modelling, 24(6), 990-1017.

Chou, W. L. (2000). Exchange rate variability and China's exports. Journal of Comparative Economics, 28(1), 61-79.

Dehn, J., Gilbert, C. L. \& Varangis, P. (2005). Agricultural commodity price volatility. Managing Economic Volatility and Crises: A Practitioner's Guide, 137-85.

Demetriades, P. \& Fielding, D. (2012). Information, institutions, and banking sector development in West Africa. Economic Inquiry, 50(3), 739-753.

Denbaly, M. \& Torgerson, D. (1992). Macroeconomic determinants of relative wheat prices: integrating the short run and long run. Journal of Agricultural Economics Research, 44(2), 27-35.

Dungey, M. \& Fry, R. (2007). The Identification of Fiscal and Monetary Policy in a Structural VAR. CFAP, 
University of Cambridge and CAMA, Australian National University [unpublished]

Dungey, M. \& Fry, R. (2009). The identification of fiscal and monetary policy in a structural VAR. Economic Modelling, 26(6), 1147-1160.

Elbourne, A. (2008). The UK housing market and the monetary policy transmission mechanism: An SVAR approach. Journal of Housing Economics, 17(1), 65-87.

Enders, W. (2004). Applied Econometric Time Series.

Essien, E. B., Dominic, A. O. \& Sunday, E. R. (n.d). Effects of Price and Exchange Rate Fluctuations on Agricultural Exports in Nigeria.

Frimpong, P. B. (2012). Population Health and Economic Growth: Panel Cointegration Analysis in SubSaharan Africa. Master's thesis at Lund University.

Gilbert, C. (2006). Trends and volatility in agricultural commodity prices. Agricultural Commodity Markets and Trade: New Approaches to Analyzing Market Structure and Instability, 31-60.

Green, W. H. (2002). Econometric Analysis. Fifth Edition Prentice Hall, Upper Saddle, River, New Jersey.

Goyal, A., Arora, S. (2010). A GARCH analysis of exchange rate volatility and the effectiveness of central bank actions, Indira Gandhi Institute of Development Research, Mumbai, 1-19.

Hanson, B. E. (2002). Tests for parameter instability in regressions with I (1) processes. Journal of Business \& Economic Statistics, 20(1), 45-59.

Idowu, E. O., Osuntogun, D. A. \& Oluwasola, O. (2007). Effects of market deregulation on cocoa (Theobroma cacao) production in Southwest Nigeria. African Journal of Agricultural Research, 2(9), 429-434.

IFPRI. (2011). 2011 Global Food Policy Report, Washington DC: International Food Policy Research Institute.

IMF. (1984). Exchange Rate Volatility and World Trade. A Study by the Research Department of IMF, occasional paper No. 28, Washington DC, IMF.

IMF. (2004). A New Look at Exchange Rate Volatility and Trade Flows. Occasional Paper No. 235.

Johnson, P. R., Grennes, T. \& Thursby, M. (1977). Devaluation, foreign trade controls, and domestic wheat prices. American Journal of Agricultural Economics, 59(4), 619-627.

Ishibashi, S. (2012). The Segmentation of Loan Interest Rates by Regional Financial Institutions: A Panel Cointegration Analysis. International Review of Business Research Papers, 8(5), 95- 110.

Kandilov, I. T. (2008). The effects of exchange rate volatility on agricultural trade. American Journal of Agricultural Economics, 90(4), 1028-1043.

Kiptui, M. (2007, July). Does the exchange rate matter for Kenya's exports? A bounds testing approach. Conference, of African Econometric Society.

Kutu, A. A., Nzimande, N. P. \& Msomi, S (2017). Effectiveness of Monetary Policy and the Growth of Industrial Sector in China. Journal of Economics and Behavioral Studies, 9(3), 46-59.

McCoy, D. (1997). How useful is Structural VAR Analysis for Irish economics? (No. 2/RT/97). Central Bank of Ireland.

Mehare, A. \& Edriss, A. K. (2012). Evaluation of Effect of Exchange Rate Variability on Export of Ethiopia's Agricultural Product: Case of Oilseeds. Evaluation, 3(11).

Moon, H. R. \& Perron, B. (2004). Testing for a unit root in panels with dynamic factors. Journal of Econometrics, 122(1), 81-126.

Ngalawa, H. \& Kutu, A. A. (2017). Modelling exchange rate variations and global shocks in Brazil. Zbornik Radova Ekonomskog fakulteta u Rijeci: časopis za ekonomsku teoriju ipraksu, 35(1), 73-95.

Ngalawa, H. \& Viegi, N. (2011). Dynamic effects of monetary policy shocks in Malawi. South African Journal of Economics, 79(3), 224-250.

Nkang, N. M., Abang, S. O., Akpan, O. E. \& Offem, K. J. (2006). Cointegration and error correction modelling of agricultural export trade in Nigeria: The case of cocoa. Journal of Agriculture and Social Sciences, 2(4), 249-255.

Nwachuku, I. N., Agwu, N., Nwaru, J. \& Imonikhe, G. (2010). Competitiveness and determinants of cocoa export from Nigeria. Report and Opinion, 2(7), 51-54.

Okunmadewa, F. (1999). Livestock industry as a tool for poverty alleviation. Nigerian Journal of Animal Science, 2(2).

Onoja, A. O., Deedam, N. J. \& Achike, A. I. (2012). Profitability and yield determinants in Nigeria cocoa farms: Evidence from Ondo State. Journal of Sustainable Development in Africa, 14(4), 172-183.

Oyinlola, M. A. (2008). Exchange Rate and Disaggregated Import Prices in Nigeria. Exchange Rate and Disaggregated Import Prices in Nigeria. Journal of Economic and Monetary Integration, 9, 89-126. 


\section{Journal of Economics and Behavioral Studies (ISSN: 2220-6140)}

Vol. 11, No. 2, pp. 1-13, April 2019

Pesaran, H. H. \& Shin, Y. (1998). Generalized impulse response analysis in linear multivariate models. Economics Letters, 58(1), 17-29.

Ramaswamy, R. \& Sloek, T. (1998). The real effects of monetary policy in the European Union: What are the differences? Staff Papers, 45(2), 374-396.

Ramey, G. \& Ramey, V. A. (1995). Cross-country evidence on the link between volatility and growth (No. w4959). National Bureau of economic research.

Schwartz, N. E. (1986). The consequences of a floating exchange rate for the US wheat market. American Journal of Agricultural Economics, 68(2), 428-433.

Sharifi-Renani, H. O. S. E. I. N. (2010). A structural VAR approach of monetary policy in Iran. In International Conference on Applied Economics-ICOAE (p. 631).

Stock, J. H. \& Watson, M. W. (2005). Implications of dynamic factor models for VAR analysis (No. w11467). National Bureau of Economic Research.

Tshibaka, T. (1997). Effects of domestic economic policies and external factors on export prices and their implications for output and income in Cameroon. AERC Final Report, Nairobi: AERC.

Verter, N. \& Bečvářová, V. (2014). Analysis of Some Drivers of Cocoa Export in Nigeria in the Era of Trade Liberalization. AGRIS on-line Papers in Economics and Informatics, 6(4).

Villanueva, J. L. J. \& Sarker, R. (2009, August). Exchange Rate Sensitivity of Fresh Tomatoes Imports from Mexico to the United States. In Contributed Paper prepared for presentation at the International Association of Agricultural Economists Conference, Beijing, China, August 16 (Vol. 22, p. 2009).

Weersink, A., Hailu, G., Fox, G., Meilke, K. \& von Massow, M. (2008). The world food crisis: Causes and the implications for Ontario agriculture (No. 46503). 